Article

\title{
Performance of a Ditch-Style Phosphorus Removal Structure for Treating Agricultural Drainage Water with Aluminum-Treated Steel Slag
}

\author{
Vinayak S. Shedekar ${ }^{1, *(\mathbb{D}, \text { Chad J. Penn }}{ }^{2}$, Lindsay Pease ${ }^{3} \mathbb{D}$, Kevin W. King ${ }^{4}$, \\ Margaret M. Kalcic ${ }^{1,5}$ and Stan J. Livingston ${ }^{2}$ \\ 1 Department of Food, Agricultural and Biological Engineering, The Ohio State University, Columbus, \\ OH 43210, USA; kalcic.4@osu.edu \\ 2 USDA-ARS National Soil Erosion Laboratory, USDA-Agricultural Research Service, \\ West Lafayette, IN 47907, USA; chad.penn@usda.gov (C.J.P.); stan.livingston@usda.gov (S.J.L.) \\ 3 Department of Soil, Water, and Climate, University of Minnesota Twin Cities, Crookston, MN 56716, USA; \\ lpease@umn.edu \\ 4 USDA-ARS Soil Drainage Research Unit, USDA-Agricultural Research Service, Columbus, OH 43210, USA; \\ kevin.king@usda.gov \\ 5 Translational Data Analytics Institute, The Ohio State University, Columbus, OH 43210, USA \\ * Correspondence: shedekar.1@osu.edu; Tel.: +1-203-321-5568
}

Received: 28 May 2020; Accepted: 24 July 2020; Published: 30 July 2020

\begin{abstract}
Several structural, treatment, and management approaches exist to minimize phosphorus (P) transport from agricultural landscapes (e.g., cover cropping and conservation tillage). However, many of these practices are designed to minimize particulate $P$ transport and are not as effective in controlling dissolved P (DP) losses. Phosphorus removal structures employ a P sorption material (PSM) to trap DP from flowing water. These structures have been successful in treating surface runoff by utilizing aluminum (Al)-treated steel slag, but subsurface tile drainage has never been tested with this material. The goal of this study was to evaluate the performance and economics of a ditch-style $P$ removal structure using Al-treated steel slag for treating agricultural subsurface drainage discharge. The structure treated subsurface drainage water from a 4.5 ha agricultural field with elevated soil test P levels. Overall, the structure removed approximately $27 \%$ and $50 \%$ of all DP and total P (TP) entering the structure, respectively (i.e., 2.4 and $9.4 \mathrm{~kg}$ DP and TP removal). After an initial period of strong DP removal, the discrete DP removal became highly variable. Flow-through analysis of slag samples showed that the slag used to construct the structure was coarser and less sorptive compared to the slag samples collected prior to construction that were used to design and size the structure. Results of this study highlight the importance of correctly designing the P removal structures using representative PSMs.
\end{abstract}

Keywords: Ohio; case study; subsurface drainage; dissolved phosphorus; phosphorus transport; phosphorus sorption materials; tile drainage; water quality; algal bloom; eutrophication

\section{Introduction}

Eutrophication due to excessive nutrient enrichment is a major concern in coastal, marine, and freshwater bodies across the world [1]. Phosphorus (P) fuels algal growth in freshwater and may significantly affect the onset, extent, and species diversity of harmful algal blooms (HABs). Nitrogen (N), on the other hand, plays a major role in driving the extent of HABs in coastal estuaries [2]. The HABs release toxic substances making the water unsuitable for drinking or recreation $[1,2]$. Eutrophication also creates hypoxic and anoxic zones, which negatively affect tourism, fisheries, and ecosystem functions [1-3]. 
Excess $\mathrm{P}$ can originate from a variety of sources. It can be transported either in particulate (i.e., bound to soil and sediment particles) or dissolved form. Particulate P poses a long-term risk, as it may become bioavailable over time. Dissolved P (DP) is immediately bioavailable to the microorganisms that are responsible for HAB development [4-7]. For example, spring DP loads are the primary driver of HABs in Lake Erie's western basin $[4,8]$.

Phosphorus can originate from point sources (e.g., wastewater treatment plants) as well as non-point sources (e.g., agricultural runoff). While point sources of DP are easier to identify and control, non-point sources tend to contribute greater $\mathrm{P}$ loads in watersheds dominated by agricultural land use. For example, the Maumee River, a major tributary to Western Lake Erie, has over $70 \%$ of its catchment under agricultural land use. It is estimated that approximately $88 \%$ of P loads come from non-point sources in the Maumee River $[9,10]$. Thus, minimizing excess nutrient runoff from agricultural landscapes is critical for protecting water quality in receiving water bodies.

Several structural, treatment, and management approaches that minimize $\mathrm{P}$ transport from agricultural landscapes are designed to limit particulate $\mathrm{P}$ transport but are not as effective in controlling DP transport [11,12]. Phosphorus removal structures are unique in that they are designed specifically to filter DP from runoff and drainage water. Phosphorus removal structures can trap DP from flowing water via reactive filter media, known as $\mathrm{P}$ sorption material (PSM). This occurs through several mechanisms that can generally be described as either precipitation with calcium (Ca) or ligand exchange onto iron (Fe) and/or aluminum (Al) oxides and hydroxides [12]. There are four basic components that are essential for a P removal structure [11]: (1) sufficient mass of a PSM with a high capacity to adsorb P; (2) targeted placement of contained PSM in a hydrologically active location; (3) a suitable flow rate of water through the PSM containing high concentrations of DP; and (4) the ability to replace the PSM once it is no longer filtering DP at the minimum desired rate.

Different types of $P$ removal structures include runoff interception box filters, in-line subsurface drainage filters, and trench- or ditch-style drainage filters. Ditch-style filters are desirable because they can be constructed within existing surface drainage ditches. Penn et al. [13] constructed and evaluated several agricultural ditch-style P removal structures. These filters treated mostly surface drainage water on the Eastern Shore of Maryland, USA. Penn et al. [13] found them to be adequate in terms of P removal. A ditch-style P removal structure has never been tested for treating water from subsurface drainage. Subsurface drainage discharge has appreciably different chemistry from surface water. Because P removal structures depend on a chemical mechanism for filtering water, it is critical to evaluate their performance with the different chemical properties of subsurface drainage discharge.

The most important design aspect of a P removal structure is the choice of PSM. A major challenge in design and construction of structures is the "paradox of PSMs", i.e., PSMs with suitable hydraulic conductivity allow water to pass through sufficiently but tend to possess little P sorption capacity, and those with greater $P$ sorption capacity often suffer from poor hydraulic conductivity.

Electric arc furnace (EAF) and blast furnace steel slag are a common and inexpensive by-product that has been shown to be an effective PSM for both wastewater and non-point source drainage [14-17]. If properly sieved to exclude fines, slag can possess an appreciable hydraulic conductivity and high $P$ retention capacity [18]. Several studies have shown that slag is effective for treating surface water runoff [19-21] even when used in a ditch-style structure [13]. Nevertheless, a recent study by Penn et al. [22] found that subsurface tile drainage water decreases the lifetime of EAF slag in P removal structures due to presence of bicarbonate. The authors suggested that a potential solution is to use Al-treated slag instead of normal EAF slag. Briefly, normal EAF slag removes $\mathrm{P}$ through precipitation of $\mathrm{Ca}$ phosphate $[17,23]$, but bicarbonate interferes with this reaction by consuming soluble $\mathrm{Ca}$ and precipitating Ca carbonate [24]. Aluminum-treated slag shifts the P removal mechanism to ligand exchange onto the surface of newly formed $\mathrm{Al}$ oxy/hydroxide minerals [21,23], which should be less sensitive to competing bicarbonate compared to Ca. However, Al-treated slag has never been field-tested for treating subsurface drainage discharge. 
The objectives of this study were to: (i) evaluate the performance of a ditch-style P removal structure through one life cycle using Al-treated steel slag for treating agricultural subsurface drainage discharge; (ii) compare field performance to expected performance based on laboratory flow-through experiments; and (iii) assess the design considerations and economics of $P$ removal.

\section{Materials and Methods}

\subsection{Site Description}

The study site was a privately-owned farm field located in Northwest Ohio near Fort Recovery in Mercer County, Ohio. A ditch-style P filter was installed at the outlet of a 4.5 ha farm field and received subsurface (tile) drainage discharge at the inlet. The dominant soil is a somewhat poorly drained Blount silt loam (Fine, illitic, mesic Aeric Epiaqualfs) [25]. The average slope of the field is $<1 \%$ and consists of randomly placed subsurface tile drains with a drainage intensity of $0.02 \mathrm{~mm}^{-2}$. The drainage system outlet is a $10.2 \mathrm{~cm}$ (4 in) pipe.

The general (historic) crop management of the field consisted of a corn (Zea mays L.)-soybean (Glycine max [Merr.]) crop rotation with cover crops during non-growing seasons in most years and rotational tillage (no-till soybeans followed by fall tillage). In general, corn received a split application of nitrogen $(\mathrm{N})$ fertilizer at planting and 30 days after planting, respectively, at rates suggested by the tri-state fertilizer recommendations [26]. The field was planted with soybean in May 2016, tilled in October 2016 following harvest, planted with alfalfa (Medicago sativa L.) and oats (Avena sativa) in April 2017, and remained in alfalfa through the end of the study period in May 2018. Nitrogen fertilizer was applied in April 2017 at a rate of $112 \mathrm{~kg} \cdot \mathrm{ha}^{-1}$. Due to elevated soil test P (STP) concentrations, no P fertilizer was applied during the study period. The STP concentrations in 2017 ranged from $430 \mu \mathrm{g} \cdot \mathrm{g}^{-1}$ Mehlich III P (M3P) near surface $(0-5 \mathrm{~cm})$ to $340 \mu \mathrm{g} \cdot \mathrm{g}^{-1} \mathrm{M} 3 \mathrm{P}$ at $15-30 \mathrm{~cm}$, and less than $14 \mu \mathrm{g} \cdot \mathrm{g}^{-1} \mathrm{M} 3 \mathrm{P}$ below $30 \mathrm{~cm}$.

The ditch was $72 \mathrm{~m}$ in length $\times 1-2 \mathrm{~m}$ in depth, constructed in trapezoidal cross-section with 4-6 m top width $\times 2 \mathrm{~m}$ bottom width. The bed of the trench was at $0.15 \%$ grade. The trench was filled with $25 \mathrm{~cm}$ of steel slag treated with aluminum sulfate, as described by [21]. The filter was constructed with $45 \mathrm{Mg}$ of steel slag material, at a porosity of $40 \%$ and designed to achieve a retention time (RT) of $5 \mathrm{~min}$ when receiving a flow rate of $25.6 \mathrm{~L} \cdot \mathrm{s}^{-1}$. This mass of PSM was utilized for achieving cumulative $35 \%$ DP removal over 4.5 years. The estimated lifetime of the filter was based on laboratory flow-through performance (described below) and historically measured annual DP loads at the location. The steel slag was obtained from TMS International, located in Cleveland, OH, USA. This was an EAF slag and was sieved by the supplier to remove particles less than $6.35 \mathrm{~mm}$ in diameter. A small dam was constructed at the upstream side of the ditch to allow water to pond and distribute evenly across the length of the PSM bed through seven perforated corrugated plastic pipes placed near the surface of the media. A set of buried pipes collected and transported the treated water out of the structure through the retention dam at the downstream side shown in Figure 1.

\subsection{Slag Characterization and Chemical Analysis}

Slag samples were collected at three different times: before installation when the P filter was designed, during installation, and when the slag was mostly ineffective at the end of the study period. Initial subsamples from the slag source to be used in construction were obtained several months before construction for laboratory determination of the P removal "design curve". The design curve and historical records of average DP loads at the selected site were then used to estimate what mass of that particular slag sample would be needed to meet the P removal goal over the selected lifetime of the structure (i.e., $35 \%$ removal at a 4.5 years cumulative DP load). These initial subsamples were sieved at the laboratory to obtain a particle size from 6.35 to $20 \mathrm{~mm}$. Then during construction, the slag delivered to the site was also subsampled and delivered to the lab for the same P removal characterization. Later, samples of spent slag were obtained at 3 different locations (near inlet, near outlet, and middle) and 
three different depths (near surface, middle, and bottom) of the structure. Slag samples were tested for DP removal under flow-through conditions as described in detail by Penn and Bowen [11]. All slag samples were tested at a $\mathrm{P}$ concentration of $1 \mathrm{mg} \cdot \mathrm{L}^{-1}$ (similar to discharge from the subsurface tile drain) and an RT of $0.32 \mathrm{~min}$. Briefly, a constant head Mariotte bottle supplied the P solution to a known mass of slag contained in a flow-through cell at a constant flow rate. The constant flow rate was calculated by dividing the desired RT by total pore volume. Outflow samples were taken every 30 min and analyzed for P. The difference between P inflow and outflow concentration is sorbed P. Phosphorus removal was expressed in terms of both discrete and cumulative removal percentage, as a function of cumulative P loading to the slag, per unit mass of slag. This normalizes the P removal curve and allows for comparison between different PSMs and conditions such as RT. In addition to the laboratory flow-through analysis conducted at $0.32 \mathrm{~min}$ RT, a $10 \mathrm{~min}$ RT was tested on the spent slag sampled from the structure at termination of the experiment. All solutions were tested for DP using the methods described below.

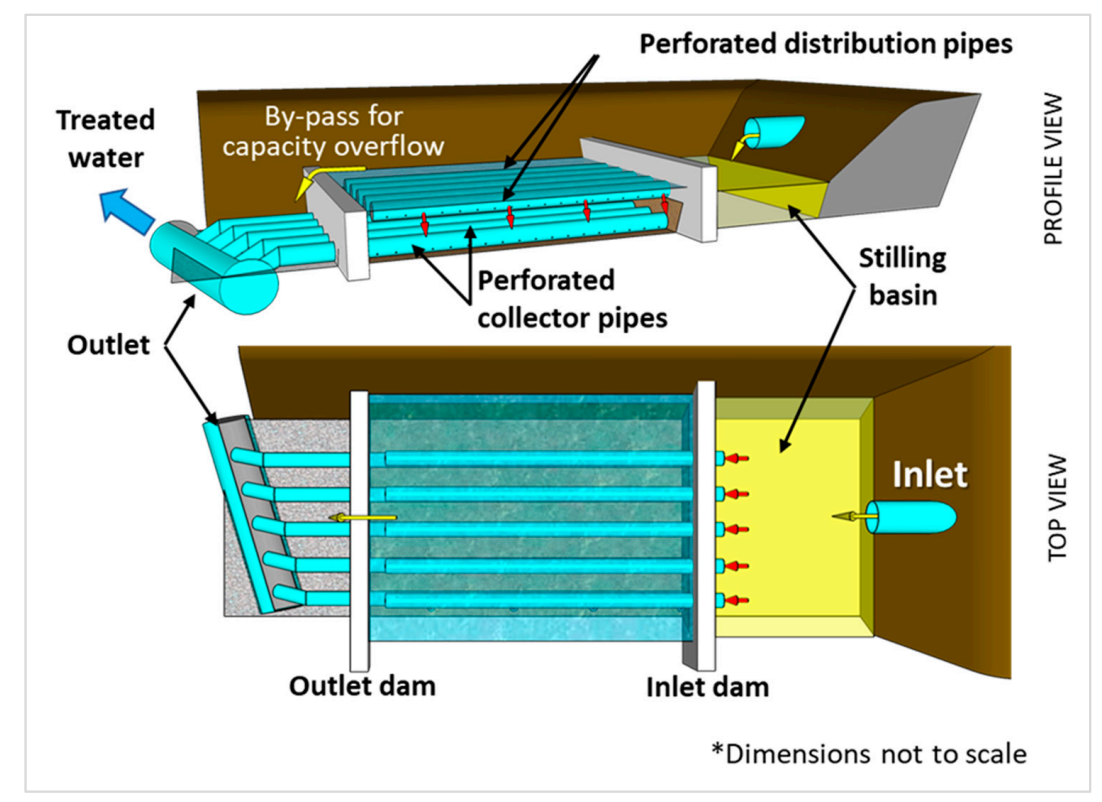

(a)
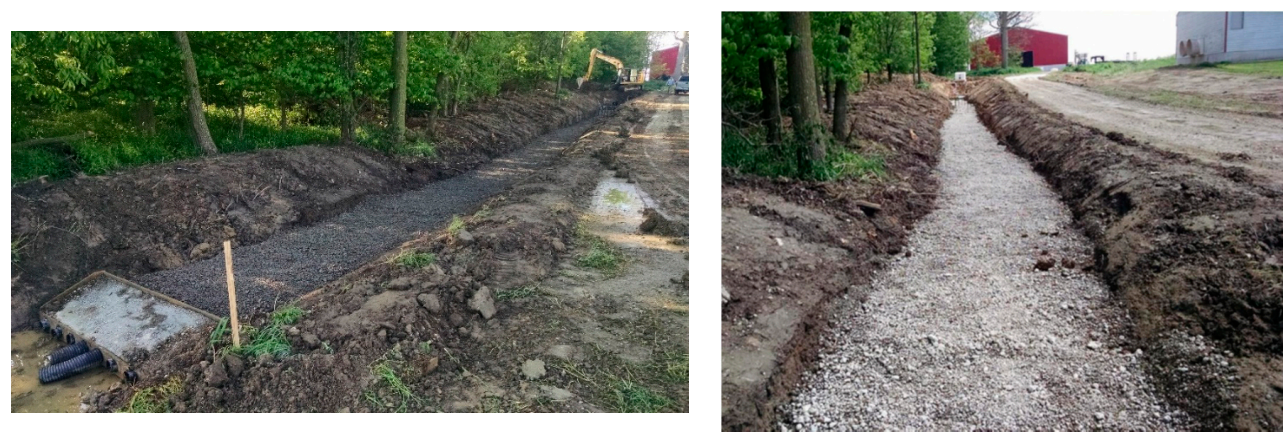

(b)

Figure 1. (a) Schematic and (b) photographs of the ditch-style phosphorus (P) removal structure constructed to treat subsurface tile drain discharge using aluminum-treated slag with top-down flow. Lower left shows the outlet dam and treated water outflow pipes. Lower right shows view from the outlet side looking towards inlet. ${ }^{*}$ The schematic is a conceptual layout. Dimensions of structure and its components are not to scale. 
The initial slag collected prior to construction and after $\mathrm{Al}$ treatment [21] was also analyzed for total digestible elements, ammonium oxalate-extractable $\mathrm{Al}$ and $\mathrm{Fe}, \mathrm{pH}$, and electrical conductivity (EC). Total digestion for elemental analysis of Al-coated slag was conducted via heated acid digestion followed by analysis of digestate with inductively coupled plasma atomic emission spectroscopy (ICP-AES) for $\mathrm{Ca}, \mathrm{Mg}$, Fe, $\mathrm{Al}, \mathrm{Mn}, \mathrm{K}, \mathrm{B}, \mathrm{Ni}, \mathrm{Pb}$, and $\mathrm{Zn}$ [27]. The $\mathrm{pH}$ and electrical conductivity (EC) of slag were measured in de-ionized (DI) water with a pH and EC meter after equilibrating slag for $30 \mathrm{~min}$ in a 1:5 solid/solution. Ammonium oxalate-extractable $\mathrm{Al}$ and Fe were determined at a solid:solution ratio of 1:40 with an equilibration time of $2 \mathrm{~h}$ and followed by measurement on ICP-AES, according to the method described by Penn and Bowen [11].

Spent slag was analyzed for sediment content that accumulated from filtration of subsurface tile drainage water. This was determined by washing $100 \mathrm{~g}$ of spent slag with $900 \mathrm{~mL}$ of de-ionized (DI) water, followed by separation of slag particles using a $2 \mathrm{~mm}$ sieve. The mass of sediment in the remaining solution was determined gravimetrically after evaporation of water. The recovered sediment was then used for determination of total P. Sediment samples were digested by the EPA 3050b method [27], followed by analysis with ICP-AES. Spent slag was analyzed for water soluble P (WSP) by equilibrating $10 \mathrm{~g}$ of slag with $100 \mathrm{~mL}$ DI water on a reciprocating shaker for $1 \mathrm{~h}$, followed by filtration with Whatman \#42 filter paper and subsequent analysis for P by the Murphy-Riley colorimetric method [28].

Water samples collected from the field structure were vacuum filtered $(0.45 \mu \mathrm{m})$ prior to analysis for DP. Dissolved P analysis was conducted using a Lachat Instruments QuikChem 8000 FIA Automated Ion Analyzer, which employs the Murphy-Riley colorimetric method [28]. Total P analysis was performed on unfiltered samples following alkaline persulfate oxidation [29] with subsequent colorimetric determination of $\mathrm{PO}_{4}$-P using ascorbic acid reduction [30]. The concentration data were used to calculate nutrient loads corresponding to each discharge event using a mid-point interpolation technique.

\subsection{Hydrologic Monitoring and Water Sampling}

The outlet of the P removal structure was a $30 \mathrm{~cm}$ diameter PVC pipe fitted with a compound weir insert (Thel-Mar, LLC; Brevard, NC, USA), Isco 4230 Bubbler Flow Meter (Teledyne Isco, Lincoln, NE, USA) and an area velocity sensor (Isco 2150, Teledyne Isco; Lincoln, NE, USA) for discharge measurement. The area velocity sensor was used to measure discharge under submerged conditions. The field outlet (i.e., inlet to the P removal structure) was retrofitted with a $30 \mathrm{~cm}$ diameter PVC pipe and monitored for discharge using a similar design. The discharge at each outlet was measured at $30 \mathrm{~min}$ intervals using a combination of a rating curve for the compound weir and data from the area velocity sensor. Precipitation was measured using both a tipping bucket rain gauge (Isco 674, Teledyne Isco; Lincoln, NE, USA) and a standard non-recording rain gauge. Williams et al. [31] described a detailed methodology for water quality data collection. Briefly, discharge from the inlet and outlet of the P removal structure was sampled for water quality using an automated water sampler (Isco 6712, Teledyne Isco; Lincoln, NE, USA). Water samples were collected every six hours and composited on a $48 \mathrm{~h}$ basis for chemical analysis. All water samples were handled according to USEPA (US Environmental Protection Agency) method 365.1 for P analysis [32]. Following collection, samples were stored below $4{ }^{\circ} \mathrm{C}\left(39^{\circ} \mathrm{F}\right)$ and generally analyzed within 28 days.

The precipitation, discharge, concentration, and load data were aggregated on daily and precipitation event basis. Precipitation events were defined as any event with a precipitation amount $\geq 6.35 \mathrm{~mm}(0.25 \mathrm{in})$ separated by at least $6 \mathrm{~h}$ with no precipitation. Thus, it was possible to have more than one rainfall event occur on the same day. The approach helps understand the system response to precipitation-induced discharge events while minimizing autocorrelation due to the baseflow from previous precipitation events. Event mean discharge was the average of point discharge measurements within an event duration. Similarly, the event flow-weighted mean concentration (FWMC) was calculated by dividing the event total load by the event total discharge. Note that some events during the study period were assumed to have the same discharge at the inlet as well as the outlet due to 
partial failure of flow monitoring instrumentation at the outlet during 2017. This approach showed strong agreement between inflow and outflow magnitudes during time periods when both inlet and outlet were monitored. The lifetime total discharge was calculated by summing the daily totals of measured discharges. Thus, the lifetime totals include the event-based discharge plus the baseflow at the inlet and outlet, respectively.

\subsection{Phosphorus Load Calculations and Data Analysis}

The P load (for DP as well as TP) for each time step (i.e., $30 \mathrm{~min}$ ) was calculated by multiplying the measured discharge by the $\mathrm{P}$ concentration. The subdaily $\mathrm{P}$ loads were then aggregated into daily totals and event totals, respectively. The lifetime P loads were calculated by summing the daily totals for the entire study period. The discrete P load ( $\left.\mathrm{mg} \cdot \mathrm{P} \cdot \mathrm{kg}^{-1} \cdot \mathrm{slag}\right)$ was then calculated by dividing the (daily) total load by the mass of steel slag. The daily P loads in the inflow and outflow were then used to calculate discrete and cumulative P removal. Discrete P removal $\left(\mathrm{mg} \cdot \mathrm{kg}^{-1}\right)$ were calculated as a mass balance: This is an example of an equation:

Discrete P removed $\left(\mathrm{mg} \cdot \mathrm{kg}^{-1} \cdot \mathrm{slag}\right)=($ Discrete P load in inflow - Discrete P load in outflow $)$

where discrete P loads in inflow and outflow are in units of $\mathrm{mg} \cdot \mathrm{kg}^{-1} \cdot$ slag. The discrete P removal (\%) was calculated with respect to inlet P load:

$$
\text { Discrete P removed }(\%)=(\text { Discrete P removed } \div \text { Discrete P load in inflow }) \times 100
$$

where discrete P removed and inflow loads are in units of $\mathrm{mg} \cdot \mathrm{kg}^{-1} \cdot \mathrm{slag}$.

Cumulative P added was calculated by summing the subsequent inflow discrete P loads. Similarly, cumulative $P$ removed was calculated by summing the subsequent outflow discrete P loads. A paired $t$-test $(\alpha=0.05)$ was used to compare inflow and outflow event mean discharges, concentrations, and loads, respectively. All statistical analyses were conducted using Minitab ${ }^{\circledR}$ statistical software (Minitab LLC; State College, PA, USA).

\section{Results and Discussion}

\subsection{Event and Lifetime Discharge}

Between May 2016 and May 2018, a total of 87 discharge events were observed at the inlet and outlet of the P removal structure. The mean event discharge at the inlet was $112.5 \mathrm{~m}^{3}\left(\sigma=141.2 \mathrm{~m}^{3}\right)$, and $102.3 \mathrm{~m}^{3}\left(\sigma=142.1 \mathrm{~m}^{3}\right)$ at the outlet (Table 1$)$. Mean event discharge at the outlet was significantly less (paired $t$-test, $p<0.01$ ) than at the inlet. A similar difference was observed in the lifetime discharge measured at the inlet and outlet $\left(11,693 \mathrm{~m}^{3}\right.$ vs. $\left.9982 \mathrm{~m}^{3}\right)$. The instantaneous flow rates at the inlet and outlet of the P removal structure ranged from zero to $3.3 \mathrm{~L} \mathrm{~s}^{-1}$. These flow rates were well below the design peak flow rates. Thus, the discharge attenuation could not be attributed to outlet overflow, since all the tile discharge passed through the P removal structure without overwhelming the outlet capacity. Discharge attenuation primarily occurred during the first several months (May through December 2016) after installation (Figure 2a), and likely resulted from lateral seepage along the ditch banks. Attempts to stabilize the newly constructed ditch with vegetation were not successful until late August of 2016. Furthermore, the natural water table in this region is typically low during the late summer and early fall season [33]. This would allow increased lateral seepage from ditch to the surrounding areas. After December 2016, event discharge was similar, and in most cases identical, between inlet and outlet. The sub-hourly event hydrographs at the inlet and outlet suggest that the retention time of water was shorter than the recording interval of $30 \mathrm{~min}$, resulting in identical hydrographs during most events (data not presented). 


\subsection{Concentrations and Loads of Dissolved P and Total P}

\subsubsection{Dissolved P Removal}

The event flow-weighted mean concentration (FWMC) of DP ranged from 0.16 to $2.3 \mathrm{mg} \cdot \mathrm{L}^{-1}$ at the inlet, and from 0 to $1.08 \mathrm{mg} \cdot \mathrm{L}^{-1}$ at the outlet. Overall FWMC of DP at the inlet was $0.7 \mathrm{mg} \cdot \mathrm{L}^{-1}\left(\sigma=0.35 \mathrm{mg} \cdot \mathrm{L}^{-1}\right)$, and that at the outlet was $0.47 \mathrm{mg} \cdot \mathrm{L}^{-1}\left(\sigma=0.28 \mathrm{mg} \cdot \mathrm{L}^{-1}\right)$ (Table 1$)$. Outlet DP concentrations were significantly less than the corresponding inlet concentrations (paired $t$-test, $\alpha=0.05$ ). Event FWMC of DP at the outlet was $32.2 \%$ less than that at the inlet. However, the difference in concentration was greater (i.e., discrete $\mathrm{P}$ removal up to $100 \%$ ) during the initial treatment period (Figure $2 \mathrm{~b}$ ) which is typical for P filtration materials. As the PSM becomes more saturated with P, its ability to further remove P diminishes [17,34]. Therefore, it is important to normalize the performance of a P removal structure (or P removal by a PSM) based on cumulative P loading to the PSM [20]. The FWMC data suggest that discrete P removal was relatively efficient for the first several events, until approximately January 2017, after which the FWMC difference between inflow and outflow generally diminished.

Table 1. Discharge, flow-weighted mean concentrations (FWMC), and loads of dissolved phosphorus (DP) and total phosphorus (TP) at the inlet and the outlet of the P removal structure summarized based on 87 discharge events and lifetime totals (monitoring period: May 2016 to May 2018).

\begin{tabular}{|c|c|c|c|c|}
\hline & \multicolumn{4}{|c|}{ Discharge } \\
\hline & Inflow $\left(\mathrm{m}^{3}\right)$ & Outflow $\left(\mathrm{m}^{3}\right)$ & Inflow (mm) & Outflow (mm) \\
\hline Event mean & 112.5 & 102.3 & 2.5 & 2.3 \\
\hline Standard deviation & 141.2 & 142.1 & 3.1 & 3.2 \\
\hline Standard error of mean & 15.1 & 15.2 & 0.3 & 0.3 \\
\hline Sum of all events & 9785 & 8904 & 218 & 196 \\
\hline \multirow[t]{5}{*}{ Lifetime total ${ }^{1}$} & 11,693 & 9982 & 260 & 222 \\
\hline & \multicolumn{4}{|c|}{ P Concentrations and Loads } \\
\hline & \multicolumn{2}{|c|}{ FWMC $\left(\mathrm{mg} \cdot \mathrm{L}^{-1}\right)$} & \multicolumn{2}{|c|}{ Load $(\mathrm{kg})$} \\
\hline & Inflow & Outflow & Inflow & Outflow \\
\hline & \multicolumn{4}{|c|}{ Dissolved Phosphorus (DP) } \\
\hline Event mean & 0.697 & 0.472 & 0.088 & 0.067 \\
\hline Standard deviation & 0.35 & 0.28 & 0.13 & 0.11 \\
\hline Standard error of mean & 0.039 & 0.031 & 0.014 & 0.011 \\
\hline Sum of all events & - & - & 7.6 & 5.8 \\
\hline \multirow[t]{2}{*}{ Lifetime total ${ }^{1}$} & - & - & 8.8 & 6.4 \\
\hline & \multicolumn{4}{|c|}{ Total Phosphorus (TP) } \\
\hline Event mean & 1.51 & 0.89 & 0.19 & 0.1 \\
\hline Standard deviation & 0.77 & 0.46 & 0.28 & 0.14 \\
\hline Standard error of mean & 0.084 & 0.052 & 0.029 & 0.015 \\
\hline Sum of all events & - & - & 16.6 & 8.7 \\
\hline Lifetime total $^{1}$ & - & - & 18.99 & 9.6 \\
\hline
\end{tabular}

${ }^{1}$ The lifetime total was calculated by summing the daily totals of measured data (discharge or P loads).

Mean event loads of DP were significantly less at the outlet $(0.067 \mathrm{~kg})$ than those at the inlet $(0.088 \mathrm{~kg})$ (paired $t$-test, $\alpha=0.05)$. The cumulative load of DP that entered and exited the P removal structure over the course of the study was 8.8 and $6.4 \mathrm{~kg}$, respectively (Table 1). Thus, the P filter removed $2.4 \mathrm{~kg}(27 \%)$ DP out of $8.8 \mathrm{~kg}$ that was measured at the inlet. In 20 out of the 87 events, the event FWMCs were greater at the outlet than at the inlet. These 20 events were associated with a relatively low fraction of the overall observed load ( $0.6 \mathrm{~kg}$ out of the $8.8 \mathrm{~kg}$ of total DP load at the inlet and $0.8 \mathrm{~kg}$ out of $6.4 \mathrm{~kg}$ of total DP at the outlet). This suggests that DP was either desorbing from the PSM or originating from somewhere other than the subsurface tile drainage. During the study period, 
it was observed that a portion of dust from poultry barns near the P removal structure was deposited directly on the P filter. According to a study conducted in Kentucky, a single broiler house facility may emit more than $785 \mathrm{~kg}$ of poultry dust per year [35]. Herron et al. [36] found that broiler poultry dust may contain 11.9 to $20.6 \mathrm{~g} \cdot \mathrm{kg}^{-1}$ of TP, of which approximately $23-54 \%$ or 3.9 to $8.3 \mathrm{~g} \cdot \mathrm{kg}^{-1}$ can be in the form of water extractable P. Although the amount and P concentration of poultry dust deposited on the P removal structure in the current study remain unknown, they may have contributed to the underestimation of the efficacy of the P filter. Furthermore, such incidental contributions offset the intended target of P removal structures, which is for removal of DP from legacy sources (i.e., soils).

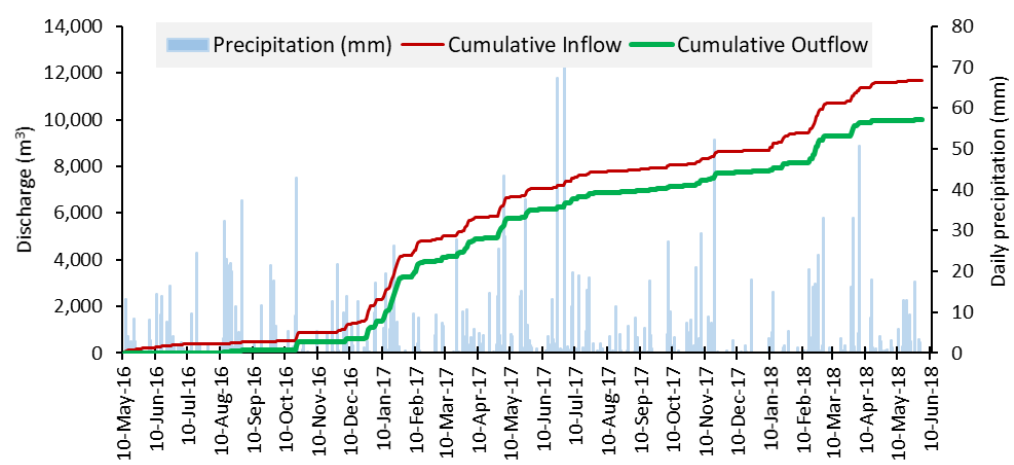

(a)

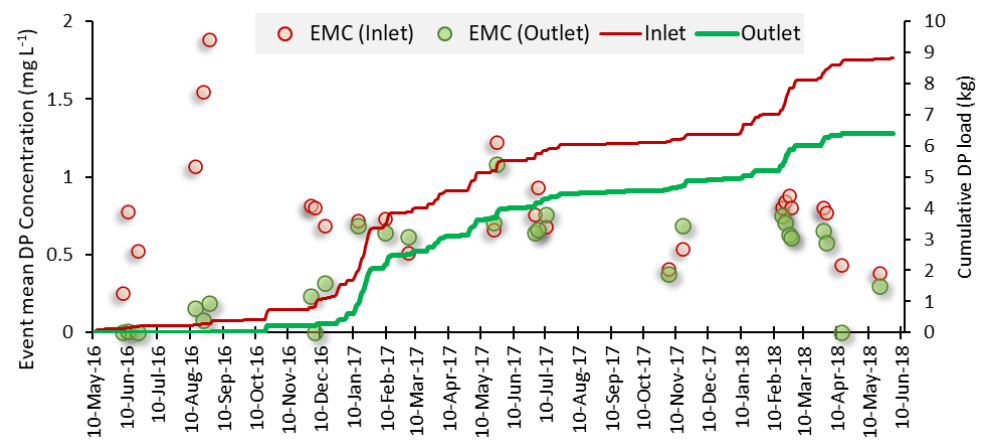

(b)

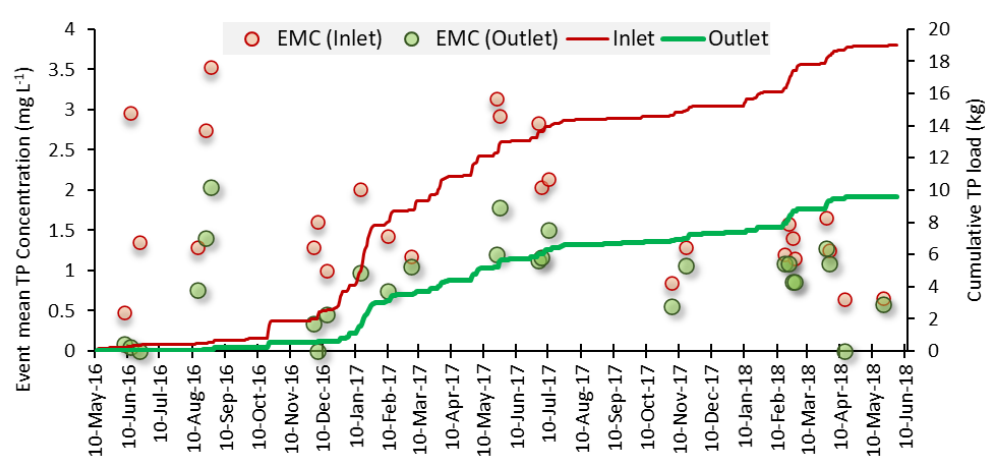

(c)

Figure 2. (a) Cumulative event discharge. (b) Event mean dissolved phosphorus (DP) concentrations (EMC) and cumulative loads and (c) event mean total P (TP) concentrations (EMC) and cumulative loads at the inlet and outlet (i.e., treated water) of the P removal structure. 
It is unlikely that the negative $P$ removal (i.e., P release) from the structure was due to desorption of DP from slag. The spent slag collected at several different locations and depths from the structure was tested for water-extractable P and was shown to release little to no DP (Seven of nine samples released no $P$ to solution, and two samples released only 0.047 and $0.09 \mathrm{mg} \cdot \mathrm{L}^{-1}$ ). Penn et al. [22] observed some small amounts of DP release from a slag filter, but the DP release was from EAF slag that had not been treated with Al. Al-treated slag should be less sensitive to competing bicarbonate than untreated slag due to the shift in the P removal mechanism to ligand exchange onto Al oxy/hydroxide minerals [21,23]. It is more likely that the negative $P$ removal was due to the unaccounted poultry dust deposits on the surface of the slag, or from desorption of $\mathrm{P}$ from trapped sediment.

The performance of the $P$ removal structure was normalized based on cumulative $P$ loading per unit mass of PSM (Figure 3). Discrete P removal was relatively efficient for the first several events, until approximately January 2017 when cumulative DP loading reached approximately $40 \mathrm{mg} \cdot \mathrm{kg}^{-1}$ (Figure 3a). Although discrete removal of DP abruptly decreased after January 2017, it was observed later in the monitoring period that removal was up to $100 \%$ for some events (Figure 3a).

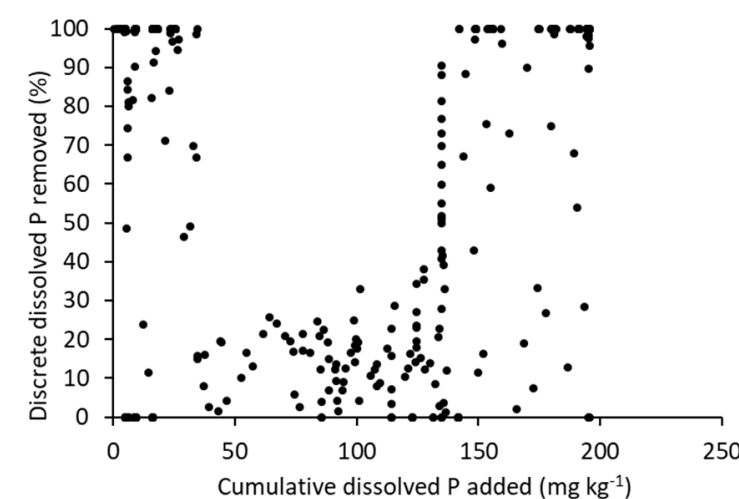

(a)

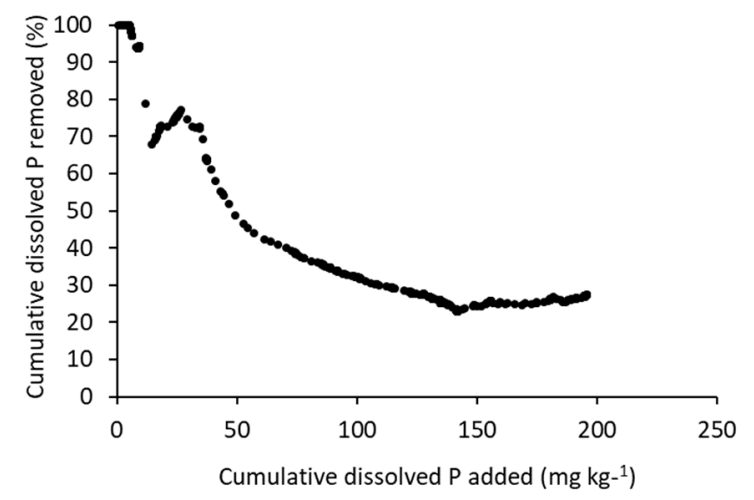

(c)

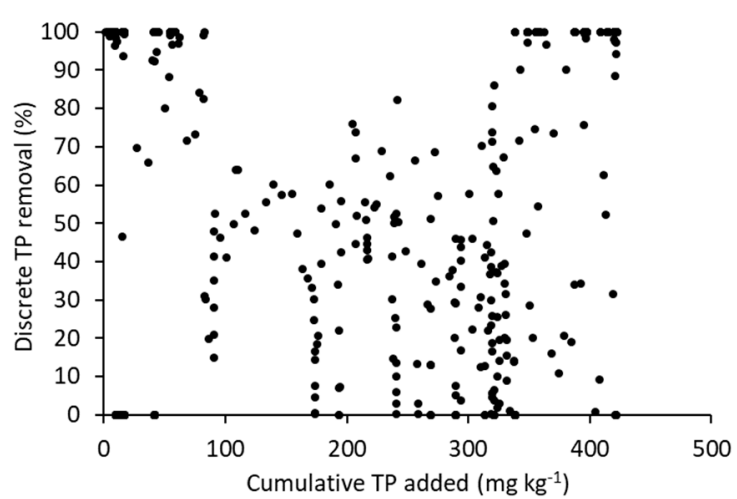

(b)

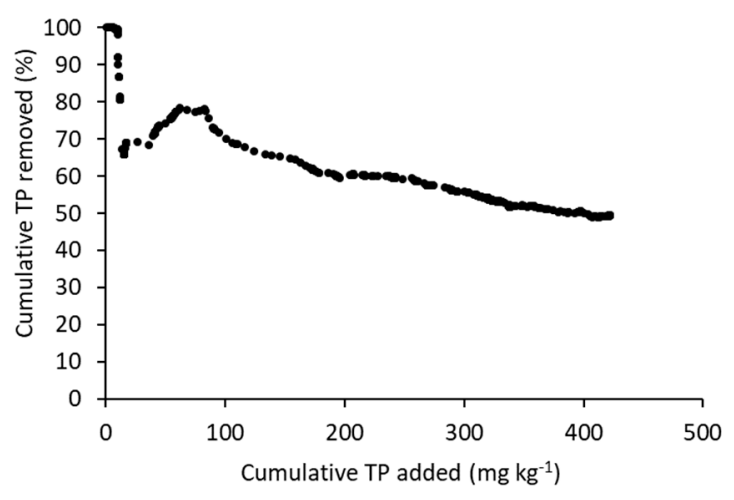

(d)

Figure 3. Discrete and cumulative removal of dissolved $P(D P)$ and total $P(T P)$ as a function of cumulative P loading to the P removal structure containing Al-treated slag. (a) Discrete removal of DP. (b) Discrete removal of TP. (c) Cumulative removal of DP. (d) Cumulative removal of TP.

Under laboratory conditions with consistent $\mathrm{P}$ input concentration and retention time, discrete DP removal always decreases with cumulative P loading [13,20,21], therefore the observed increase in DP removal suggests changes in the conditions. Over a narrow range of cumulative $P$ loading (up to $30 \mathrm{mg} P$ added per $\mathrm{kg}$ slag), the P removal is independent of the retention time. However, after the PSM becomes partially saturated with $\mathrm{P}$, it does become sensitive to retention time, such that almost no $\mathrm{P}$ was removed during high-flow events (i.e., short retention time), while some $\mathrm{P}$ was removed during low 
flow events that provided relatively longer retention time. This may explain why the filter performance was highly variable near the end of the monitoring period. For example, a flow-through analysis of the spent slag revealed that when utilizing a short retention time (i.e., fast flow rate), P removal was near zero, whereas the longer retention time resulted in appreciable DP removal (Figure 4). Wang et al. [34] present similar results where an increase in retention time increases $P$ removal. An extensive review by Mendes [12] showed high variability of $P$ removal in systems receiving event-driven variable discharge compared to those with more stable hydrologic regime. In addition to retention time, increased inflow DP concentration generally improves discrete P removal compared to lesser inflow concentrations, at equal P loading; this is due to greater chemical potential for sorption reactions to occur [17]. Inflow DP concentrations ranged from less than 0.25 to $2.3 \mathrm{mg} \cdot \mathrm{L}^{-1}$ (Figure $2 \mathrm{~b}$ ).

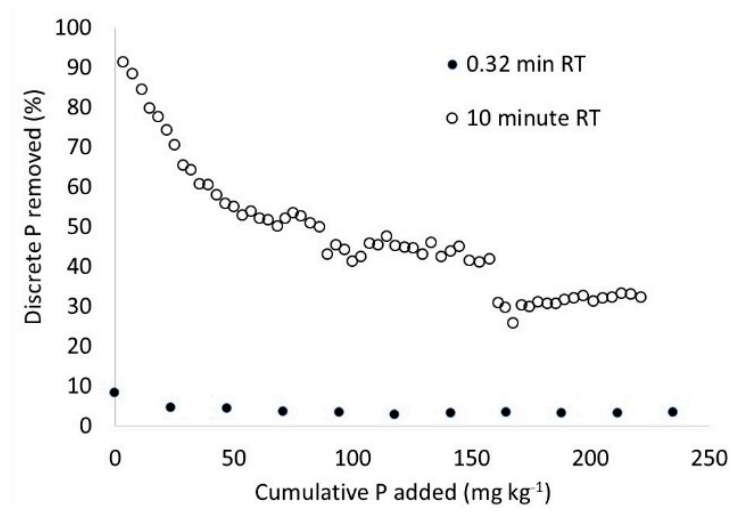

Figure 4. Comparison of discrete dissolved phosphorus (P) removal at retention times (RT) of 0.32 and $10 \mathrm{~min}$, for the spent Al-treated slag collected at termination of the study. Discrete P removal was measured in laboratory flow-through cells using $1 \mathrm{mg} \cdot \mathrm{P} \cdot \mathrm{L}^{-1}$ and expressed as a function of cumulative P loading.

\subsubsection{Total P Removal}

The FWMC of TP ranged from 0.3 to $3.3 \mathrm{mg} \cdot \mathrm{L}^{-1}$ at the inlet, and from $10^{-5}$ to $2.9 \mathrm{mg} \cdot \mathrm{L}^{-1}$ at the outlet. The FWM TP concentrations at the inlet were $1.5 \mathrm{mg} \cdot \mathrm{L}^{-1}\left(\sigma=0.77 \mathrm{mg} \cdot \mathrm{L}^{-1}\right)$, and those at the outlet were $0.89 \mathrm{mg} \cdot \mathrm{L}^{-1}\left(\sigma=0.46 \mathrm{mg} \cdot \mathrm{L}^{-1}\right)$. A paired $t$-test $(\alpha=0.05)$ showed that the concentrations at the outlet were significantly less than those at the inlet, and therefore the FWMC of TP at the outlet was approximately $41 \%$ less than that at the inlet. In some cases (11 out of 87 ), the FWMCs were greater at the outlet than those at the inlet, suggesting additional TP contribution from the structure (Figure 2c). These 11 events were associated with 0.19 out of $9.5 \mathrm{~kg}$ of total TP at the outlet. One possibility is that the ditch sidewall eroded and released some sediment during those events, which in turn contributed to increased TP loads. The cumulative loads of TP during the study period were $19 \mathrm{~kg}$ (event mean $=191 \mathrm{~g}, \sigma=275 \mathrm{~g}$ ) at the inlet, and $9.6 \mathrm{~kg}$ (event mean $=100 \mathrm{~g}, \sigma=140 \mathrm{~g}$ ) at the outlet for a net TP removal of approximately $50 \%(9.4 \mathrm{~kg})$ by the P removal structure. Figure $3 \mathrm{~d}$ illustrates cumulative TP removal as a function of cumulative TP input. Notice that after a decrease from $100 \%$ to $55 \%$, cumulative removal was fairly stable after addition of approximately $100 \mathrm{mg} \cdot \mathrm{TP} \cdot \mathrm{kg}^{-1}$. This is unlike the cumulative DP removal curve (Figure 3c), where DP removal was steeper, i.e., more rapid decrease with further loading. The differences between TP and DP removal were expected since TP removal is mostly a physical process of trapping sediment while DP removal involves chemical reactions.

The slag bed visibly accumulated sediment, although the exact source is unknown; a greater percentage of it is probably from the construction of the ditch filter itself, before re-vegetation of banks. The laboratory analysis of spent slag samples from the ditch filter suggested that the P removal structure trapped approximately $6.4 \mathrm{Mg}$ of sediment during the study period. Total P concentration of the sediment captured by slag was $901 \mathrm{mg} \cdot \mathrm{P} \cdot \mathrm{kg}^{-1}$ sediment. Sediment transported in flowing water is typically enriched in P compared to bulk field soils due to the preferential transport of clay and silt-sized particles, which contain the majority of soil P [37]. 
Further, this captured sediment represents approximately $5.7 \mathrm{~kg}$ of TP. The P filter provided an excellent environmental service by trapping sediment that otherwise would have transported into a receiving wetland or a stream further downstream. However, if a majority of sediment was from construction or bank erosion, then this potentially undermined the primary intended function of the practice, i.e., removal of legacy $\mathrm{P}$ loads from the contributing farm field.

\subsection{Predicted vs. Measured Dissolved P Removal and Comparison to Other Studies}

The slag filter was designed using slag characteristics and flow-through experiments conducted several months prior to construction (Table 2).

Table 2. Physical and chemical properties of the aluminum-treated slag collected prior to construction and used in design of the phosphorus $(\mathrm{P})$ removal structure. Concentrations of elements are total values or ammonium oxalate extractable, as indicated. $\mathrm{BD}=$ below detection.

\begin{tabular}{ccc}
\hline Parameter & Units & Value \\
\hline & Physical properties & \\
\hline Porosity & $\%$ & 40 \\
Mean particle size & $\mathrm{Mm}$ & 13.8 \\
Bulk density & $\mathrm{g} \cdot \mathrm{cm}^{-3}$ & 1.65 \\
\hline & Chemical & \\
\hline properties & \\
\hline Electrical conductivity & $\mathrm{mS} \cdot \mathrm{cm}^{-1}$ & 5.65 \\
Total Ca & $\mathrm{g} \cdot \mathrm{kg}^{-1}$ & 2.76 \\
Total Mg & $\mathrm{g} \cdot \mathrm{kg}^{-1}$ & 235 \\
Total Fe & $\mathrm{g} \cdot \mathrm{kg}^{-1}$ & 32.7 \\
Total Al & $\mathrm{g} \cdot \mathrm{kg}^{-1}$ & 125 \\
Total Mn & $\mathrm{g} \cdot \mathrm{kg}^{-1}$ & 37.5 \\
Total K & $\mathrm{mg} \cdot \mathrm{kg}^{-1}$ & 14.8 \\
Total Cr & $\mathrm{mg} \cdot \mathrm{kg}^{-1}$ & 267 \\
Total Ni & $\mathrm{mg} \cdot \mathrm{kg}^{-1}$ & 1523 \\
Total Pb & $\mathrm{mg} \cdot \mathrm{kg}^{-1}$ & 153 \\
Total Zn & $\mathrm{mg} \cdot \mathrm{kg}^{-1}$ & 1.6 \\
Total B & $\mathrm{mg} \cdot \mathrm{kg}^{-1}$ & 125 \\
Oxalate Fe & $\mathrm{mg} \cdot \mathrm{kg}^{-1}$ & $\mathrm{BD}$ \\
Oxalate Al & $\mathrm{mg} \cdot \mathrm{kg}^{-1}$ & 2759 \\
& & 671 \\
\hline
\end{tabular}

Specifically, we used the original pre-structure P removal curve to design a structure that would achieve DP removal of $200 \mathrm{mg} \cdot \mathrm{kg}^{-1} \cdot \mathrm{slag}$, corresponding to cumulative inflow loading of $600 \mathrm{mg} \cdot \mathrm{kg}^{-1}$ slag (i.e., overall 35\% removal; Figure 5a). Comparing cumulative DP removal at equal loading of $200 \mathrm{mg} \cdot \mathrm{kg}^{-1}$, the field structure only removed $50 \mathrm{mg} \cdot \mathrm{kg}^{-1}$ (30\%) compared to $125 \mathrm{mg} \cdot \mathrm{kg}^{-1}(\sim 65 \%)$ for the slag tested prior to construction (Figure 5). This suggested that the slag used to construct the structure was different from the slag tested prior to construction. In fact, the slag delivered and utilized by the construction contractor contained a much larger size fraction than what was originally planned. The original slag sample tested in the lab for P removal ranged in size from 6.35 to $20 \mathrm{~mm}$, whereas the material delivered to the site for construction contained an appreciably amount with particles $>50 \mathrm{~mm}$. The construction contractor later communicated that they purposely changed the plan by screening the slag for obtaining larger particles. This was a critical contributing factor to the short lifespan of the filter because $\mathrm{P}$ removal by both normal and Al-coated slag is strongly dependent on particle size, as particle size is inversely proportional to surface area and solubility. For example, Penn et al. [38] showed that inclusion of smaller diameter slag particles dramatically increased DP removal. 


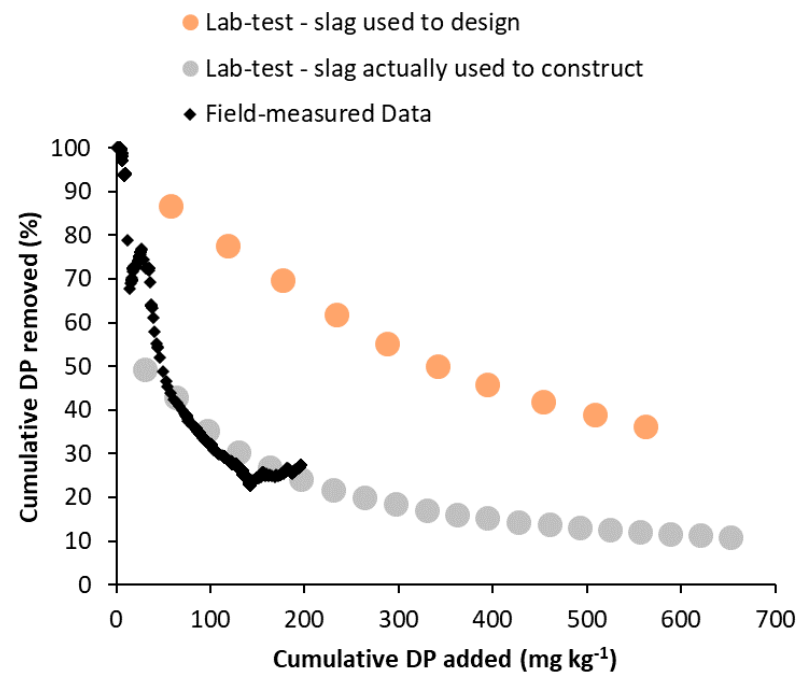

(a)

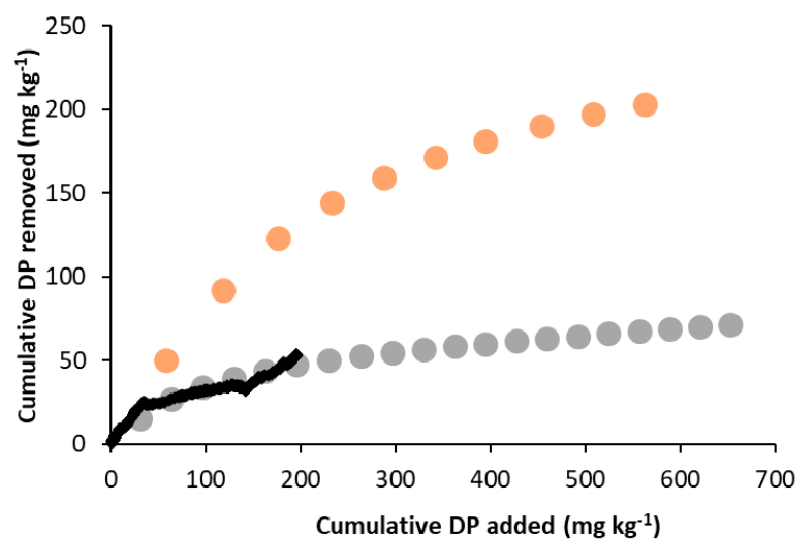

(b)

Figure 5. Cumulative dissolved phosphorus (DP) removal measured in the field P removal structure (black dots) compared to laboratory testing of the same slag contained in the P removal structure (grey dots), and a different slag sample initially tested for conducting the design of the structure (orange dots). Dissolved P removal expressed as both \% (a) and $\mathrm{mg} \cdot \mathrm{kg}^{-1} \mathrm{slag}(\mathbf{b})$. Laboratory tests conducted at $1 \mathrm{mg} \cdot \mathrm{L}^{-1}$ inflow DP concentration and $0.32 \mathrm{~min}$ retention time.

Laboratory analysis further confirmed that the relatively coarser PSM used for construction had much less removal capacity than the material used for designing the structure. When normalized for loading, Figure 5 indicates that the lab-tested slag sample performed similarly to the field P removal structure, consisting of the same slag material.

Therefore, underperformance of the P removal structure relative to the design goal appears to be due to the fact that a different and less sorptive slag material was used in construction compared to the slag sample initially tested for conducting the design. While the P removal "design curve" is the heart of the design of a P removal structure, Penn and Bowen [11] stressed that proper design of a P removal structure is strongly dependent on using $\mathrm{P}$ removal design curve parameters that are representative of the conditions and PSM utilized at the site.

Dissolved P removal was appreciably greater compared to normal non-treated slag utilized at the same site in a different experiment. That structure had problems with clogging and the slag became quickly "spent" due to reactions with bicarbonate from the inflow subsurface tile drainage water; details of this study are described in Penn et al. [22]. Several ditch P removal structures were 
constructed and evaluated on the Eastern Shore of Maryland [13]. Although these structures contained slag, none of them had Al-coated slag. Performance of those was not as favorable as the P removal structure presented in this paper; for example, a typical ditch structure in that study was only able to remove $28 \%$ or 19 out of $66 \mathrm{mg} \cdot \mathrm{kg}^{-1}$ cumulative DP input while the structure discussed in this paper removed $27 \%$ or 54 out of $200 \mathrm{mg} \cdot \mathrm{kg}^{-1}$ cumulative DP input. Compared to other studies that utilized Al-coated slag, performance was similar. A pond filter described in Penn and McGrath [21] removed a total of $54 \mathrm{mg} \cdot \mathrm{kg}^{-1}(36 \%)$ at a cumulative input of $149 \mathrm{mg} \cdot \mathrm{kg}^{-1}$. A different pond filter at the same site removed 35 and $28 \%$ with 233 and $285 \mathrm{mg} \cdot \mathrm{kg}^{-1}$ of cumulative DP input (as cited by [20]). A surface-confined bed P removal structure, designed to intercept barn-yard runoff from a poultry farm in Oklahoma was able to remove $21 \%$ of $560 \mathrm{mg} \cdot \mathrm{kg}^{-1}$ cumulative DP added over two years [20].

\subsection{Design Considerations and Costs}

The $0.15 \%$ bed slope of the pre-existing ditch limited the available hydraulic head difference between the inlet and the outlet. Therefore, it was necessary to use a relatively thin layer of slag $(25 \mathrm{~cm})$, causing $45 \mathrm{Mg}$ of slag to be spread over a long distance. Uniform distribution of water in a top-down flow regime over such a long distance $(72 \mathrm{~m})$ is difficult to achieve. In retrospect, construction of the structure utilizing a bottom-up flow regime [22] would have allowed for a thicker slag bed, thereby minimizing the length. While such a design would reduce the maximum flow rate for the structure, it is feasible since the flow rates measured at the site were only a fraction of the maximum design capacity of the structure.

Traditional ditch P removal structures (i.e., structures constructed in pre-existing ditches) are constructed with less difficulty and cost [13]. Much of the expense for construction of the structure described in this study was due to the need to create a ditch for transport of discharged water from the subsurface tile drain. Cost of slag plus transportation was approximately 2000 US dollars (USD). However, it was later discovered that closer slag sources were present. Total cost of the structure, including payment to the construction contractor for labor, materials, and Al-coating of slag, was approximately 10,000 USD. Considering total DP removal of $2.4 \mathrm{~kg}$, this structure was very expensive at approximately 4167 USD per kg DP removed. Cost of TP removal was much less, at approximately 1000 USD per $\mathrm{kg}$ removed, which is similar to the cost of wastewater treatment. However, after the initial cost of construction, replacement of the PSM in the structure will be much less expensive since the structure has already been built. For example, future plans include replacing spent slag with a gravel-metal shavings mixture that will cost less than 5000 USD.

\section{Summary and Conclusions}

The performance and economics of a ditch-style P removal structure using Al-treated steel slag were assessed for treating agricultural subsurface drainage discharge. The structure treated subsurface drainage water from a 4.5 ha agricultural field with elevated soil test P levels. Overall, the structure removed approximately $27 \%$ and $50 \%$ of all DP and TP entering the structure from the upstream field's subsurface drainage system, respectively (i.e., 2.4 and $9.4 \mathrm{~kg}$ DP and TP removal). The discrete DP removal became highly variable after an initial period of strong DP removal. This was likely a result of variation in inflow DP concentration and flow rates resulting in variable retention times. Flow-through analysis of the spent slag collected at termination of the study showed that with uniform contact and a 10 min retention time, the spent slag still had considerable P sorption potential compared to the same material tested at a 0.32 min retention time. Achieving uniform distribution of inflow water is difficult to accomplish over a long distance (72 $\mathrm{m}$ in this study); in this regard, it would have been better to construct the structure with a thicker slag bed and reduced the length of the structure. The Al-coated slag utilized to treat subsurface tile drainage water was much more effective than the normal non-treated slag tested in the same P removal structure, described by Penn et al. (2020). Bicarbonate contained in subsurface tile drainage water interfered less with $P$ removal reactions on Al-treated slag than normal slag that is dominated with $\mathrm{Ca}$ [22]. Due to lower than expected performance and high transportation 
expenses, the cost per kg DP removed was very high at approximately 4167 USD and 1000 USD per kg TP removed. However, the reusability of structure is expected to lower the future cost of DP removal.

While the P removal structure may have removed less DP than expected, partly due to sediment influx and unaccounted direct deposits of poultry litter dust on top of the slag bed, the P removal performance of the structure was comparable and in some cases better than those reported in other studies. Furthermore, laboratory analyses provided clear evidence that the slag used to construct the structure was less sorptive compared to the slag samples collected prior to construction, which was used to design and size the structure. The lesser ability of the two slag samples appeared to be due to differences in particle size, where the slag used to construct the structure possessed a much larger size fraction than slag used for design and initially predicting performance. As demonstrated in the current study, controlling the influx of sediment, especially from bank erosion, is another important design consideration. The sediment contributes to clogging as well as a reduction in treatment capacity of the P filter. Additionally, if the sediment contains a significant P concentration, it further reduces the treatment capacity of the structure. These results highlight the importance of conducting the design of $P$ removal structures using $P$ removal design curve parameters that are representative of the conditions and PSM that will be used in the P removal structure, and ensuring consistency between design plans and actual construction in the field.

Author Contributions: Conceptualization, C.J.P. and S.J.L.; methodology, C.J.P., V.S.S., and K.W.K.; funding acquisition, K.W.K.; formal analysis, V.S.S., C.J.P. and L.P.; investigation, C.J.P., V.S.S. and K.W.K.; data curation, K.W.K.; writing —original draft preparation, V.S.S.; writing—review and editing, C.J.P., L.P., K.W.K., M.M.K. and S.J.L. All authors have read and agreed to the published version of the manuscript.

Funding: Funding for this research was in part from USDA Natural Resources Conservation Service (NRCS) Mississippi River Basin Initiative (MRBI) and Conservation Effects Assessment Project (CEAP). This research is a contribution from the USDA Long-Term Agroecosystem Research (LTAR) network.

Acknowledgments: The authors would also like to acknowledge the support of Jed Stinner, Sara Henderson, and Katie Rumora in field installation and collection of measurement data and water samples. Eric Fischer, Marie Pollock, and many undergraduate students contributed to the laboratory analysis of water samples. The authors would also like to thank the cooperating farmers for allowing access to the farm and cooperation in implementing the project tasks. Asmita Murumkar provided editing comments on the manuscript drafts during internal reviews.

Conflicts of Interest: The authors declare no conflict of interest.

\section{References}

1. King, K.W.; Williams, M.R.; Macrae, M.L.; Fausey, N.R.; Frankenberger, J.; Smith, D.R.; Kleinman, P.J.A.; Brown, L.C. Phosphorus Transport in Agricultural Subsurface Drainage: A Review. J. Environ. Qual. 2015, 44, 467-485. [CrossRef] [PubMed]

2. Rabalais, N.N.; Turner, R.E.; Wiseman, W.J.; Wiseman, W.J. Gulf of Mexico Hypoxia, aka “The Dead Zone". Annu. Rev. Ecol. Syst. 2002, 33, 235-263. [CrossRef]

3. Rockwell, D.C.; Warren, G.J.; Bertram, P.E.; Salisbury, D.K.; Burns, N.M. The US EPA Lake Erie indicators monitoring program 1983-2002: Trends in phosphorus, silica, and chlorophyll a in the central basin. J. Great Lakes Res. 2005, 31, 23-34. [CrossRef]

4. Stumpf, R.P.; Johnson, L.T.; Wynne, T.T.; Baker, D.B. Forecasting annual cyanobacterial bloom biomass to inform management decisions in Lake Erie. J. Great Lakes Res. 2016, 42, 1174-1183. [CrossRef]

5. Baker, D.B.; Confesor, R.; Ewing, D.E.; Johnson, L.T.; Kramer, J.W.; Merryfield, B.J. Phosphorus loading to Lake Erie from the Maumee, Sandusky and Cuyahoga rivers: The importance of bioavailability. J. Great Lakes Res. 2014, 40, 502-517. [CrossRef]

6. Kane, D.D.; Conroy, J.D.; Peter Richards, R.; Baker, D.B.; Culver, D.A. Re-eutrophication of Lake Erie: Correlations between tributary nutrient loads and phytoplankton biomass. J. Great Lakes Res. 2014, 40, 496-501. [CrossRef]

7. Scavia, D.; David Allan, J.; Arend, K.K.; Bartell, S.; Beletsky, D.; Bosch, N.S.; Brandt, S.B.; Briland, R.D.; Daloğlu, I.; DePinto, J.V.; et al. Assessing and addressing the re-eutrophication of Lake Erie: Central basin hypoxia. J. Great Lakes Res. 2014, 40, 226-246. [CrossRef] 
8. Wilson, R.S.; Beetstra, M.A.; Reutter, J.M.; Hesse, G.; Fussell, K.M.D.; Johnson, L.T.; King, K.W.; LaBarge, G.A.; Martin, J.F.; Winslow, C. Commentary: Achieving phosphorus reduction targets for Lake Erie. J. Great Lakes Res. 2019, 45, 4-11. [CrossRef]

9. Ohio-EPA. Nutrient Mass Balance Study for Ohio's Major Rivers; Ohio-EPA Division of Surface Water, Modeling and Assessment Section: Columbus, OH, USA, 2016.

10. Ohio-EPA. Nutrient Mass Balance Study for Ohio's Major Rivers; Ohio-EPA Division of Surface Water, Modeling and Assessment Section: Columbus, OH, USA, 2018.

11. Penn, C.J.; Bowen, J.M. Design and Construction of Phosphorus Removal Structures for Improving Water Quality; Springer: Berlin/Heidelberg, Germany, 2017.

12. Dantas Mendes, L.R. Edge-of-Field Technologies for Phosphorus Retention from Agricultural Drainage Discharge. Appl. Sci. 2020, 10, 634. [CrossRef]

13. Penn, C.; Bowen, J.; McGrath, J.; Nairn, R.; Fox, G.; Brown, G.; Wilson, S.; Gill, C. Evaluation of a universal flow-through model for predicting and designing phosphorus removal structures. Chemosphere 2016, 151, 345-355. [CrossRef]

14. Weber, D.; Drizo, A.; Twohig, E.; Bird, S.; Ross, D. Upgrading constructed wetlands phosphorus reduction from a dairy effluent using electric arc furnace steel slag filters. Water Sci. Technol. 2007, 56, 135-143. [CrossRef] [PubMed]

15. Sellner, B.M.; Hua, G.; Ahiablame, L.M.; Trooien, T.P.; Hay, C.H.; Kjaersgaard, J. Evaluation of industrial by-products and natural minerals for phosphate adsorption from subsurface drainage. Environ. Technol. 2019, 40, 756-767. [CrossRef] [PubMed]

16. Penn, C.J.; Bryant, R.B.; Callahan, M.P.; McGrath, J.M. Use of Industrial By-products to Sorb and Retain Phosphorus. Commun. Soil Sci. Plant Anal. 2011, 42, 633-644. [CrossRef]

17. Stoner, D.; Penn, C.; McGrath, J.; Warren, J. Phosphorus Removal with By-Products in a Flow-Through Setting. J. Environ. Qual. 2012, 41, 654-663. [CrossRef] [PubMed]

18. Edgar, M.; Ray, H.; Grubb Dennis, G.; van Paassen Leon, A.; Hamdan, N.; Boyer Treavor, H. Removal of Phosphate and Nitrate from Impacted Waters via Slag-Driven Precipitation and Microbial Transformation. J. Sustain. Water Built Environ. 2020, 6, 04020007. [CrossRef]

19. Penn, C.J.; McGrath, J.M.; Rounds, E.; Fox, G.; Heeren, D. Trapping Phosphorus in Runoff with a Phosphorus Removal Structure. J. Environ. Qual. 2012, 41, 672-679. [CrossRef] [PubMed]

20. Penn, C.; Chagas, I.; Klimeski, A.; Lyngsie, G. A review of phosphorus removal structures: How to assess and compare their performance. Water 2017, 9, 583. [CrossRef]

21. Penn, C.J.; McGrath, J.M. Predicting Phosphorus Sorption onto Steel Slag Using a Flow-through approach with Application to a Pilot Scale System. J. Water Resour. Prot. 2011, 3, 235-244. [CrossRef]

22. Penn, C.; Livingston, S.; Shedekar, V.; King, K.; Williams, M. Performance of Field-Scale Phosphorus Removal Structures Utilizing Steel Slag for Treatment of Subsurface Drainage. Water 2020, 12, 443. [CrossRef]

23. Qin, Z.; Shober, A.L.; Scheckel, K.G.; Penn, C.J.; Turner, K.C. Mechanisms of Phosphorus Removal by Phosphorus Sorbing Materials. J. Environ. Qual. 2018, 47, 1232-1241. [CrossRef]

24. Claveau-Mallet, D.; Courcelles, B.; Comeau, Y. Phosphorus removal by steel slag filters: Modeling dissolution and precipitation kinetics to predict longevity. Environ. Sci. Technol. 2014, 48, 7486-7493. [CrossRef] [PubMed]

25. Soil Survey Staff. Keys to Soil Taxonomy, 12th ed.; USDA-Natural Resources Conservation Service: Washington, DC, USA, 2014.

26. Vitosh, M.; Johnson, J.; Mengel, D. Tri-State Fertilizer Recommendations for Corn, Soybeans, Wheat and Alfalfa; Michigan State Extension: East Lansing, MI, USA, 1995.

27. USEPA. Acid Digestion of Sediments, Sludges and Soils, Method-3050B.; USEPA: Washington, DC, USA, 1996.

28. Murphy, J.; Riley, J.P. A modified single solution method for the determination of phosphate in natural waters. Anal. Chim. Acta 1962, 27, 31-36. [CrossRef]

29. Patton, C.J.; Kryskalla, J.R. Methods of Analysis by the US Geological Survey National Water Quality Laboratory: Evaluation of Alkaline Persulfate Digestion as an Alternative to Kjeldahl Digestion for Determination of Total and Dissolved Nitrogen and Phosphorus in water; US Department of the Interior, US Geological Survey: Denver, CO, USA, 2003.

30. Parsons, T.; Maita, Y.; Lalli, C. A manual of chemical and biological methods for seawater analysis. Pergamon, Oxford sized algae and natural seston size fractions. Mar. Ecol. Prog. Ser. 1984, 199, 43-53. 
31. Williams, M.R.; King, K.W.; Ford, W.; Fausey, N.R. Edge-of-field research to quantify the impacts of agricultural practices on water quality in Ohio. J. Soil Water Conserv. 2016, 71, 9A-12A. [CrossRef]

32. USEPA Phosphorus, all forms. Method 365.1 (colorimetric, automated, ascorbic acid). Available online: https://gentechscientific.com/document_library/methods/method_365-1_1993.pdf (accessed on 1 July 2020).

33. Williams, M.; King, K.; Fausey, N. Contribution of tile drains to basin discharge and nitrogen export in a headwater agricultural watershed. Agric. Water Manag. 2015, 158, 42-50. [CrossRef]

34. Wang, L.; Penn, C.; Huang, C.; Livingston, S.; Yan, J. Using Steel Slag for Dissolved Phosphorus Removal: Insights from a Designed Flow-Through Laboratory Experimental Structure. Water 2020, 12, 1236. [CrossRef]

35. Burns, R.T.; Hong, L.; Lara, M.; Xin, H.; Rich, G.; Doug, O. John Earnest Quantification of Particulate Emissions from Broiler Houses in the Southeastern United States. In Proceedings of the Livestock Environment VIII, Iguassu Falls, Brazil, 31 August-4 September 2008.

36. Herron, S.L.; Brye, K.R.; Sharpley, A.N.; Miller, D.M.; Daniels, M.B. Nutrient Composition of Dust Emitted from Poultry Broiler Houses in Northwest Arkansas. J. Environ. Prot. 2015, 6, 1257. [CrossRef]

37. Sharpley, A.N. The Enrichment of Soil Phosphorus in Runoff Sediments. J. Environ. Qual. 1980, 9, 521-526. [CrossRef]

38. Penn, C.; Bell, G.; Wang, Z.; McGrath, J.; Wilson, S.; Bowen, J. Improving the ability of steel slag to filter phosphorus from runoff. Turfgrass Environ. Res. Online 2014, 13, 1-5.

(C) 2020 by the authors. Licensee MDPI, Basel, Switzerland. This article is an open access article distributed under the terms and conditions of the Creative Commons Attribution (CC BY) license (http://creativecommons.org/licenses/by/4.0/). 